
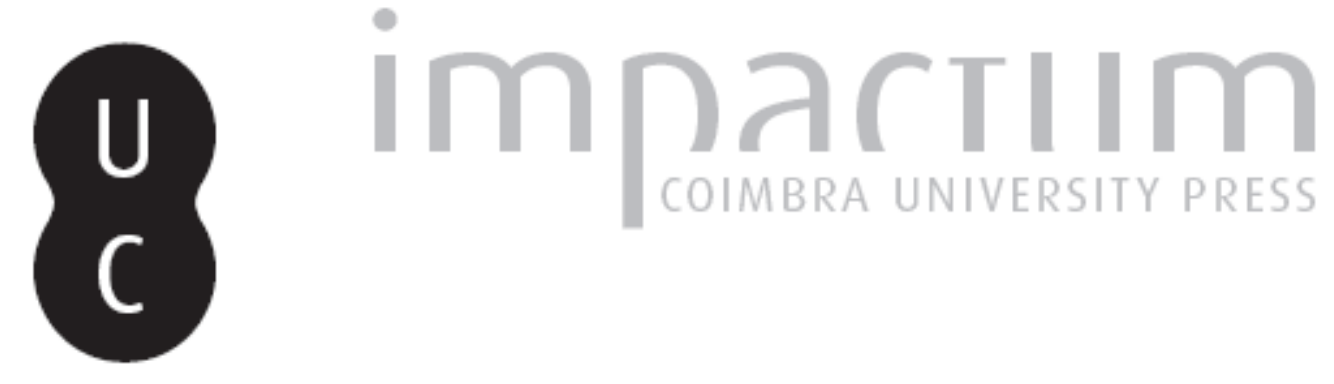

\title{
O império contra-ataca: a produção secreta de propaganda feita por estrangeiros para projecção internacional de "portugal do ultramar"
}

\author{
Autor(es): $\quad$ Piçarra, Maria do Carmo
}

Publicado por: Imprensa da Universidade de Coimbra

URL persistente:

URI:http://hdl.handle.net/10316.2/39629

DOI:

DOI:http://dx.doi.org/10.14195/2183-5462_29_3

Accessed : $\quad$ 26-Apr-2023 15:57:09

A navegação consulta e descarregamento dos títulos inseridos nas Bibliotecas Digitais UC Digitalis, UC Pombalina e UC Impactum, pressupõem a aceitação plena e sem reservas dos Termos e Condições de Uso destas Bibliotecas Digitais, disponíveis em https://digitalis.uc.pt/pt-pt/termos.

Conforme exposto nos referidos Termos e Condições de Uso, o descarregamento de títulos de acesso restrito requer uma licença válida de autorização devendo o utilizador aceder ao(s) documento(s) a partir de um endereço de IP da instituição detentora da supramencionada licença.

Ao utilizador é apenas permitido o descarregamento para uso pessoal, pelo que o emprego do(s) título(s) descarregado(s) para outro fim, designadamente comercial, carece de autorização do respetivo autor ou editor da obra.

Na medida em que todas as obras da UC Digitalis se encontram protegidas pelo Código do Direito de Autor e Direitos Conexos e demais legislação aplicável, toda a cópia, parcial ou total, deste documento, nos casos em que é legalmente admitida, deverá conter ou fazer-se acompanhar por este aviso.

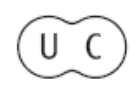




\section{Media Jornalismo}

\section{MÉDIA E COLONIALISMO(S)}




\title{
O IMPÉRIO CONTRA-ATACA: \\ A PRODUÇÃO SECRETA DE PROPAGANDA FEITA \\ POR ESTRANGEIROS PARA PROJECÇÃO INTERNACIONAL \\ DE "PORTUGAL DO ULTRAMAR"1
}

\author{
THE EMPIRE STRIKES BACK: \\ THE SECRET PRODUCTION OF PROPAGANDA BY FOREIGN \\ DIRECTORS TO GAIN INTERNATIONAL PROJECTION FOR THE \\ "PORTUGAL OF THE OVERSEAS"
}

\author{
MARIA DO CARMO PIÇARRA \\ UNIVERSIDADE DO MINHO, CENTRO DE ESTUDOS DE COMUNICAÇÃO E SOCIEDADE \\ E CENTRO DE ESTUDOS COMPARATISTAS DA FACULDADE DE LETRAS \\ DA UNIVERSIDADE DE LISBOA \\ 4710-057 BRAGA, PORTUGAL \\ CARMORAMOS@GMAIL.COM
}

Resumo

Quando se iniciou a contestação internacional à posse de colónias por Portugal, como é que o Estado Novo usou o cinema na projecção de uma retórica luso-tropical? A partir de 1965, vários documentários realizados pelos franceses Jean-Noel Pascal-Angot e Jean Leduc foram exibidos internacionalmente, no circuito comercial de distribuição cinematográfica, em festivais, nas televisões e mostrados às principais organizações não governamentais. 0 financiamento desta produção supostamente independente - em que o Brasil era apontado como o modelo social em recriação em Angola enquanto que o funcionamento da Commonwealth era assumidamente inspirador em Moçambique -, dando enfoque ao desenvolvimento económico e social, foi mantido confidencial. "Do Minho a Timor somos todos portugueses" era a "evidência" que este cinema encomendado queria impor.

Através da análise de filmes de propaganda do colonialismo português realizados por realizadores franceses questiono, porém, se a afirmação do "orgulhosamente sós" foi uma declinação retórica, para afirmação da política colonial internamente, enquanto para o exterior se projectava, progressivamente e com maior intensidade durante o Marcelismo mas ainda durante o Salazarismo, a imagem de outro Portugal, menos espartilhado, em termos de costumes, e aberto ao capital estrangeiro.

1 Menção de apoio: Este artigo foi produzido no âmbito do projeto de pós-doutoramento com a referência SFRH/BPD/93217/2013, cofinanciado pela Fundação para a Ciência e Tecnologia (FCT) e pelo Fundo Social Europeu (FSE) - Programa Operacional Potencial Humano (POPH), no âmbito do Quadro de Referência Estratégico Nacional (QREN) Portugal 2007-2013. 


\section{PalaVRas-chave}

Luso-tropicalismo; propaganda cinematográfica; Estado Novo; filmes coloniais; projecção cinematográfica; representações coloniais; filme-palimpsesto; discurso

\section{Abstract}

When the United Nations began to question the possession of colonies by Portugal, how were films used by Estado Novo to project a luso-tropical rhetoric?

From 1965, documentaries directed by French filmmakers Jean-Noel Pascal-Angot and Jean Leduc were showed internationally in cinemas, film festivals, televisions and were presented to the major non-governmental organizations. The Portuguese regime's funding to this production supposedly independent - in which Brazil was appointed as the social model in recreation in Angola and the functioning of the Commonwealth was presented as inspiring for Mozambique - was kept confidential. "From Minho to Timor we are all Portuguese" was the "evidence" that this commissioned film production wanted to impose.

Through the analysis of these international colonial propaganda films commissioned by Portuguese regime, I question, however, if Salazar's claim of Portugal standing "proudly alone" was a rhetorical declination, only to affirm internally the colonial policy, while abroad it was being projected an image of another Portugal, less corseted in terms of customs, and open to foreign capital.

\section{KEYWORDS}

Luso-tropicalism; cinematographic propaganda, Estado Novo/ New State; CoIonial Cinema; film projection; colonial representations ,; film-palimpsest; discourse

Este ensaio é um contributo para a análise da projecção do colonialismo português através do cinema, com um enfoque particular na história da produção de filmes assegurada, a partir de meados dos anos 60, por realizadores franceses. Que papel desempenharam estes filmes, exibidos internacionalmente, no circuito comercial de distribuição cinematográfica, em festivais, televisões e apresentados às principais organizações não governamentais, na promoção nacional e internacional de um suposto luso-tropicalismo característico de Portugal, concebido como multirracial, multi-cultural e pluricontinental??

0 financiamento pelo Estado Novo desta produção supostamente independente em que o Brasil era apontado como o modelo social em recriação em Angola enquanto que o funcionamento da Commonwealth era assumidamente inspirador no caso de Moçambique -, dando enfoque ao desenvolvimento económico e social, promovido, também supostamente, pela administração colonial portuguesa, foi mantido confidencial.

Inspirado nos Cadernos do cárcere e nas Cartas do cárcere de Gramsci [cruzando também outra influência, a de A ordem do discurso, de Foucault, e aprofundando 0 que já fizera em Orientalismo, ao considerar o conjunto da escrita sobre o Oriente

2 Uma versão preliminar e mais curta deste ensaio foi publicada, com o título "0 império contra-ataca: produção secreta de filmes coloniais para projecção mundial" em Os cinemas dos países Iusófonos. V Simpósio internacional/VII Mostra. Coord. Jorge Cruz e Leandro Mendonça. UERJ/UFF Rio de Janeiro: Edições LCV. 
como um discurso, em Culture and Imperialism], Edward Said analisa textos literários tomados como fonte para entender as dinâmicas da política e da cultura nas suas relações com o imperialismo. Através do comentário a obras primas ocidentais argumenta que foi por via da cultura que o imperialismo ocidental se legitimou e "conquistou" o mundo impondo-lhe o seu modelo económico. Said sustenta que poder e ideologia trabalharam para criar e manter um sistema de dominação que funciona para além da dominação militar. Analisou a linguagem, imagens e símbolos usados nas narrativas "orientalistas" para mostrar como a natureza formativa e não meramente expressiva destas moldou identidade, imaginação, subjectividade, história, cultura e interacção entre opressor e oprimido. Conclui que estas imagens moldaram historicamente a forma como o Ocidente concebeu negativamente 0 "outro", justificando assim a sua obrigação de dominar.

Evoco Said para sustentar a análise que proponho sobre a ordem do Estado Novo subjacente ao discurso cinematográfico durante a ditadura no que se refere especificamente ao colonialismo. Note-se que, tanto em Portugal como noutros países europeus, são escassos os estudos sobre como o cinema representou as ex-colónias, predominando antes aqueles com enfoque na literatura. Apoio-me, pois, numa proposição de Jean-Michel Frodon (1998) - a de que a nação partilha com o cinema a necessidade de projecção de modo a poder existir. Em La projection nacionale. Cinéma et nation, Frodon constata como, a partir do último terço do século XIX e durante todo o século XX, a sociedade das nações se tornou a forma dominante de organização social. Paralelamente nota que 0 cinema se impôs no século XX como o novo modo de criação artística, produtor de mitologias e do prazer de massas.

As propostas de Frodon sublinham a solidariedade gerada entre a história das nações e a do cinema e a sua hegemonia durante todo o século XX. Adicionalmente, 0 autor afirma haver uma comunhão na natureza de ambos: existem e não podem existir de outro modo que não seja por via da projecção. Este mecanismo partilhado é da sua natureza.

$\mathrm{Na}$ análise do conceito de nação, Frodon parte da estabelecida por Benedict Anderson (1983), segundo a qual nação é "uma comunidade política imaginária e imaginada como intrinsecamente limitada e soberana". Assumindo a definição de Anderson, a comunidade é ficcional porque imaginária e que é imaginada como limitada e soberana (o imaginário nacional) através da projecção, interiorizada intimamente mas através de um processo colectivo, de uma memória "oficial" - que, nos estados totalitários é, no limite, um magma em que a memória individual deve ser coincidente com a colectiva.

Frodon propõe que a nação se inventa a partir de um real revisto e corrigido segundo uma dramaturgia. Vai mais longe, e propõe que os mesmos critérios usados para definir naçã̃o se aplicam exactamente ao cinema. Escreve que é a projecção de um traço da realidade que funda o cinema e o distingue de todas as técnicas comparáveis precedentes. Esta é feita em grande formato, no escuro, perante uma assembleia voluntária de indivíduos que partilham, sem se verem, a mesma "visão magnificada".

0 Estado Novo coroa a transição para o autoritarismo iniciada como a revolução militar de 28 de Maio de 1926 e é o epílogo de um processo de combate e repressão às organizações políticas e sindicais da Primeira República. 
0 desenvolvimento de uma ideologia nacionalista de legitimação do novo regime impôs-se e tornou-se necessária a sua divulgação. Através do modernismo, 0 ideólogo do regime, António Ferro - o director do Secretariado da Propaganda Nacional (SPN), criado em 1933, em quem Salazar confiou para "projectar" a nação -, procura estetizar a cultura tradicional, propondo um revisionismo histórico e estético da "portugalidade" . ${ }^{3}$ Como é que o Estado Novo fez a projecção nacional através do cinema? Ferro convenceu Salazar - entre outras medidas - a financiar directamente a produção cinematográfica em português para educar o "espírito" do povo. Não obstante o financiamento de obras de propaganda cinematográfica explícita e da produção, pelo próprio SPN, de documentários e actualidades de propaganda, só em 1948 foi criado um organismo, o Fundo Nacional do Cinema (FNC), que veio definir o modelo de filme a promover, para beneficiar do apoio estatal. 0 filme devia, pois, "ser representativo do espírito português, quer traduza a psicologia, os costumes, as tradições, a história, a alma colectiva do povo, quer se inspire nos grandes temas da vida e cultura universais" (Lei $n^{0} 2027$, de 18 de Fevereiro de 1948). Este objectivo balizou limites para a criação cinematográfica, constrangendo os autores a abordar temas que pudessem beneficiar dos apoios do FCN.

Até ao início da guerra colonial, o cinema português - sobretudo o ficcional interessou-se pouco pelas colónias. As excepções - documentais, quase exclusivamente - ocorreram quase sempre com motivações políticas fortes subjacentes, devido ao desconhecimento profundo existente em Portugal sobre as colónias e seus habitantes. Iniciada a Guerra Colonial em 1961, o regime quis mudar isso, à semeIhança, aliás, da ditadura militar, logo após o golpe de 1926, a qual foi bastante rápida, não obstante a crise financeira, a instrumentalizar o cinema.

\section{"Portugal não é um País Pequeno" projectado Pelo cinema nacional}

Foi a propaganda a levar a câmara de filmar para as ex-colónias portuguesas. Logo em 1909, Ernesto de Albuquerque filma, em S. Tomé, A cultura do cacau, do qual subsiste uma sequência de um minuto. 0 filme é uma resposta a acusações da empresa Cadbury relativas à existência de trabalho forçado nas ilhas da linha do Equador. É, porém, uma excepção que confirma a regra: a Primeira República não se interessou muito pelo cinema.

Passar-se-ão vinte anos antes que uma câmara de filmar enviada pelo Estado português regresse a S. Tomé, com a Brigada Cinematográfica Portuguesa, dirigida por Fernandes Thomaz, que, em 1929, filma a longa-metragem Uma visita às propriedades da sociedade agricola Valle Flôr, Limitada na ilha de S. Thomé. Filma-se também, com realização de Augusto Seara, São Tomé agrícola e industrial.

Estes títulos, que atestam a importância da propaganda económica relativa às colónias, integram já a produção promovida pela ditadura militar chegada ao poder em 1926, enquanto define uma política colonial - 0 que é feito previamente à Constituição que, em 1933, legitima o Estado Novo -, consubstanciada no Acto Colonial. 0 novo

3 Transfigurado em Secretariado Nacional da Informação (SNI), em 1944.

Após o afastamento de Ferro do SPN, em 1948, não apareceu ninguém capaz de formular uma política cultural tão marcante quanto aquela que Ferro concebeu e mesmo o seu sucessor mais dinâmico, César Moreira Baptista, manteve a "política do espírito" como referência. 
regime ainda está a organizar as finanças quando determina a participação nas grandes exposições coloniais europeias: Exposição Ibero-americana de Sevilha (1929), Exposição Internacional e Colonial de Antuérpia (1930) e Exposição Colonial de Paris (1931).

Por indicação do então ministro das Colónias, Armindo Monteiro, a primeira iniciativa estatal para produzir filmes sobre as colónias africanas, que veio a ser concretizada pelo sucessor de Monteiro, Francisco Vieira Machado, foi dirigida pelo Agente Geral das Colónias e comissário da Exposição de Sevilha, Armando Cortesão ${ }^{4}$, que contratou três equipas. Foram elas a dos Serviços Cartográficos do Exército, a que se juntou Augusto Seara; a da Missão Cinegráfica a Angola, composta por César de Sá e António Antunes da Mata; e a da Brigada Cinematográfica Portuguesa, liderada por Fernandes Thomaz. Além do financiamento da Agência Geral das Colónias (AGC), a produção dos filmes beneficiou do apoio de empresas privadas e da administração local. ${ }^{5}$

Os filmes desta primeira missão ficam-se, em geral, pelo registo da paisagem com imagens em movimento sem acrescentar mais do que faria uma sucessão de imagens fixas fotografadas mecanicamente. Os intertítulos, explicativos, fazem a ligação entre sequências. Em geral, não são mostrados muitos colonos e os "nativos" também não merecem grande atenção.

Má qualidade da fotografia, iluminação e enquadramento, ausência de sentido artístico e científico, titulação incorrecta e reveladora de mau conhecimento dos sítios, da sua geografia e etnografia, foram algumas críticas feitas aos filmes. ${ }^{6}$ As obras foram mostradas sobretudo em sessões de propaganda, pelo que, durante anos, as imagens das colónias portuguesas quase desapareceram do circuito comercial de exibição. Uma excepção foi Île et Angola Pullman, de René Ginet, que estreou, em Abril de 1935, com o título S. Tomé - Jóia do império.

Previamente, porém, à encomenda estatal de filmes para a participação em exposições, e além de Cultura do cacau, que filmes coloniais foram feitos? Poucos,

4 A Agência Geral das Colónias foi fundada no final de 1924 "para preencher uma falta de informação e de divulgação sobre as colónias". Integrou um "movimento [europeu] pela divulgação das riquezas e dos valores tropicais e também como procuradora e intermediária dos interesses dos Governos de cada uma das possessões ultramarinas" (Garcia, 2011: 119-120). Em 1951 é transformada em Agência Geral do Ultramar (AGU) e vê as competências alargadas ao turismo. Mesmo quando 0 departamento de propaganda é extinto, seis anos depois, continua a promover reportagens (de cinema, também) relativas a acontecimentos no Ultramar.

5 Dos filmes feitos actualmente existem: Costumes primitivos dos indígenas em Moçambique (1929), Festejos em Lourenço Marques pela passagem dos territórios do Niassa para a posse do Estado (1929), Guiné - Aspectos industriais e agricultura (1929), São Tomé agrícola e industrial (1929), Estradas e paisagens de Angola (1929), Quedas do Dala (1930); Aspectos do rio Quanza. Quedas do Lucala (1930); Planalto de Huíla(1931), Acção colonizadora dos portugueses (1932), De Lisboa a Luanda (1932), 0 deserto de Angola (1932), Pesca da baleia em Angola (1932) e Fazenda açucareira "Tentativa"(1932), De Lisboa a São Tomé(1933).

60 operador de fotografia, César de Sá, escreveu à Cinéfilo nº 77 (1930, p. 25) sobre 0 caso concreto de Angola afirmando que "não houve realização nenhuma na verdadeira acepção do termo". Explica: "[...] só entendo realização de um filme quando há um trabalho mental preparatório, que neste caso não existiu" e que "[...] foi da Comissão Executiva da Exposição de Sevilha que recebi a indicação geral dos assuntos a filmar e foi depois in loco, com a minha 'Debrie' e com os meus conhecimentos práticos, que tive que resolver essa tal questão da realização". 
documentais e sobretudo de propaganda, embora deva assinalar-se a actividade de Manuel Antunes Amor, amador que filmou as únicas obras feitas - hoje desaparecidas - na "Ásia portuguesa" até meados do século XX. Não se conhecem, porém, quaisquer filmes coloniais realizados na segunda década do século XX. Além das imagens sobreviventes do filme feito em S. Tomé, o filme mais antigo da colecção colonial da Cinemateca Portuguesa (CP) é de 1923 - Angola - Exposição provincial, agrícola, industrial e pecuária.

Se a propaganda visada pela AGC através da primeira missão cinematográfica foi posta em causa por motivos imputados aos realizadores, tal não obstou a que 0 Estado aderisse à prática do momento, copiando outros impérios: trazer o "outro" para exposição, em autênticos zoos humanos, na metrópole. Em 1931, no âmbito de uma feira industrial em Lisboa, instala-se uma aldeia indígena no recinto, com as respectivas palhotas, famílias, animais domésticos, artesãos, provenientes da Guiné. Dois filmes registam o acontecimento: África em Lisboa - Exposição dos indígenas da Guiné na grande exposição industrial portuguesa e Guiné - Aldeia indígena em Lisboa. Em 1933, a vinda a Portugal de uma companhia indígena de Angola ficou também registada em $A 1^{a}$ Companhia de infantaria indígena de Angola em Lisboa. Na primeira exposição colonial, que aconteceu no Porto, em 1934, Aníbal Contreiras foi encarregue de filmar Primeira exposição colonial portuguesa e Cortejo colonial do Porto que fixam igualmente a exibição de "nativos" no evento.

Em 1936 a AGC retoma o esforço de propaganda filmada das colónias. "I cruzeiro de férias às colónias de África Ocidental" fixa a viagem em que estudantes, entre os quais Ruy Cinatti, por iniciativa da revista Mundo Português - patrocinada pela AGC e pelo SPN -, foram levados pela propaganda do regime para ver que Portugal "não era um país pequeno". 0 filme não teve mais do que uma projecção, não obstante ter sido filmado pelo maior fotógrafo de arte de então, Manuel Alves San Payo. Se é um caderno filmado de viagem onde, aqui e além, há vislumbres do talento de San Payo, o certo é que é um filme pouco apelativo, marcado pelo ritmo intenso da viagem, que não demora o olhar sobre as colónias, e cumpre 0 papel propagandista do modo mais literal: mostrando vistas e a incursão dos viajantes no espaço colonial.

Criada em 1937, a Missão Cinegráfica às Colónias de África, que visou a produção de filmes que traduzissem o esforço colonizador e o nível de desenvolvimento alcançado, é um investimento de vulto na propaganda. Além do registo da visita presidencial às colónias de 1938, a missão filma os exteriores para o filme de ficção Feitiço do império. Dela resultarão vários documentários que foram sendo estreados ao longo da década de 40: Guiné, berço do império (1940), Aspectos de Moçambique e S. Tomé e Príncipe (1941), Angola, uma nova Lusitânia e Gentes que nós civilizámos (1944), As ilhas crioulas de Cabo Verde (1945) e Guiné portuguesa (1946).

Avalie-se a importância desta produção colonial no âmbito da propaganda estatal por via da reflexão, feita em 1944, pelo Agente Geral das Colónias, Júlio Cayolla que posteriormente foi o delegado do SNI na supervisão da produção de Chaimite, apoiado pelo FCN.? Elogiando o suposto desenvolvimento empreendido pós-Acto

7 Cayolla, J. (1944). A propaganda colonial como elemento de formação duma consciência imperial. Boletim Geral das Colónias, N²28 - XX, 184. 
Colonial, sustenta que é justo que se deseje mais (Cayolla, 1944, pp. 34-35). Pede, entre outras propostas, que "a propaganda pelo cinema, [seja feita] quer com filmes de fundo evocando grandes figuras da nossa história, quer com pequenos documentários em que se veja o actual desenvolvimento das nossas colónias". Preconiza-se, pois, a continuidade do investimento dos documentários de propaganda económica a par de uma produção ficcional de que Chaimite é a ilustração justa.

A visão de Cayolla "fez escola", portanto, até o movimento do Novo Cinema impor novos temas e um novo olhar sobre os territórios. Apesar da realização de um filme ficcional que não é mais do que um mau "safari cinematográfico", Chikwembo! Sortilégio africano (Carlos Marques, 1953), o grande filme do regime pós-Feitico do império é Chaimite (Brum do Canto, 1953), que enaltece as figuras de Paiva Couceiro e Mouzinho de Albuquerque, e é um elogio da obra militar portuguesa, do trabalho dos colonos e faz um retrato menos paternalista dos negros africanos do que Feitiço fizera. Manteve-se escassa, porém, a produção de propaganda colonial de longa-metragem ficcional. Predominaram os documentários e actualidades cinematográficas que visaram sobretudo dar conta do progresso técnico e económico nas ex-colónias mas com irregularidade e dependendo quase sempre de apostas pontuais na produção sistemática de filmes.

No pós-guerra, e com o Plano Marshall em curso, a AGC promoveu a realização de vários filmes de propaganda económica assegurados por Felipe de Solms e Ricardo Malheiros. Decorrente dessa iniciativa, em 11 de Agosto de 1950, a Agência promove a projecção, no Tivoli, em Lisboa, dos primeiros oito documentários produzidos em Angola e Moçambique pela dupla Solms e Malheiro, com 0 apoio financeiro das Câmaras Municipais de Luanda, Lobito, Lourenço Marques e Beira, as Juntas de Exportação de Angola e Moçambique, os Serviços de Instrução Pública de Angola e a Associação dos Produtores de Sisal de Moçambique. Com fotografia de Alfredo Gomes e João Silva, os textos, escritos por Henrique Galvão, tiveram locução de Pedro Moutinho. 0 Boletim Geral das Colónias n $302-$ 303, que noticiou o evento, esclarece que os filmes integravam um programa de produção então em curso. A edição posterior revela que, no mês seguinte, os mesmos filmes foram apresentados em Coimbra e no Porto, respectivamente no Teatro Avenida e no Cinema Batalha. Também Miguel Spiguel veio a filmar, para o Estado português, uma série de documentários de propaganda económica e turística. Nada, porém, que se compare ao que veio a suceder com a aprovação, em meados da década de 60, do Plano Ultramar.

Na sequência da II Guerra Mundial alteram-se as relações de poder no mundo. Emergem novas nações na sequência do êxito de movimentos de libertação em vários territórios. 0 regime, que se proclama só enquanto procura, paradoxalmente, ser reconhecido como parceiro mundial, desenvolve uma retórica sobre a especificidade do colonialismo português. Neste período agudiza-se porém a crise colonial, iniciada com as exigências de integração pela Índia dos territórios do Goa, Damão e Diu. A década de 50 é de nova declinação do modelo político colonial. Até à década de 40, inclusive, este teve subjacente uma visão antropobiológica - que definiu um padrão de raça portuguesa e opôs-se à miscigenação - disseminada pelas figuras referenciais das escolas antropológicas de Coimbra e do Porto, Eusébio Tamagnini e Mendes Correia. 
Com a revisão constitucional de 1951, devido às emergências do anti-colonialismo pós II Guerra Mundial e dos novos países do chamado "Terceiro Mundo", abandonam-se, em Portugal, os conceitos de império e de colónia. Tal é consagrado na Lei Orgânica do Ultramar de 1953, que reflecte um princípio integracionista e reforça a unidade do território metropolitano e ultramarino. Ao conceito de império sucede 0 de nação pluricontinental em que todos os territórios são Portugal e constituem a Nação.

Sarmento Rodrigues, ministro das Colónias desde 1950, acciona a reforma administrativa não descurando a reforma ideológica do modelo político colonial. Este assimila então - adaptando-o e despojando-o da componente sexual ${ }^{8}$ - o luso-tropicalismo, teoria do sociólogo brasileiro Gilberto Freyre, sobre um multiculturalismo assente num denominador comum: a especificidade da adaptação do português e sua cultura a ambientes tropicais. ${ }^{9}$

Quando Freyre publicou, em 1940, 0 mundo que o português criou lançou os fundamentos da concepção de um espaço identitário que perduram na lusofonia. Segundo essa concepção Portugal, Brasil, África, a “Índia Portuguesa" constituíam uma "unidade de sentido e de cultura" dentro de uma tendência para a mestiçagem. Freyre propõe que tal unidade foi sustentada pelo cristianismo português, ideia posteriormente usada pelo Estado Novo na resposta à questionação internacional sobre a manutenção de colónias.

Na década de 40, porém, as posições de Freyre eram ainda incompatíveis com a influência da antropobiologia no modelo colonial. É que se o cristianismo português e a "aptidão de transplantador", para os trópicos, dos valores europeus, são enquadráveis na ideologia do Estado Novo, a importância dada à mestiçagem e a componente sexual da teoria foram recalcadas.

Quando a guerra colonial começa em Angola, no início de 1961, o regime de Salazar aprofunda a utilização da retórica luso-tropical, para projecção internacional sobretudo, e afirma que há um "modo português de estar no mundo". 0 Brasil é assumido como exemplar do espírito multicultural da "portugalidade" e apontado como o modelo social em implementação em Angola, enquanto o desenvolvimento económico, na saúde e na educação acelera. Os documentários da década de 60 espelham essa retórica embora o regime se tenha socorrido de realizadores franceses - Jean Leduc e Jean Noel Pascal-Angot - para mais eficazmente projectar a nação multirracial e pluricontinental.

Salazar, conhecido por gerir as finanças com contenção, não regateou recursos quando recebeu uma proposta de propaganda por Pascal-Angot, realizador de documentários internacionalmente reconhecido. A condição fundamental para 0 apoio não foi, porém, tanto o prestígio do realizador em causa mas o plano de difusão internacional das obras. A propaganda queria investir-se de credibilidade - aparente pelo menos - e visava a projecção do colonialismo, de sabor luso-tropical, em

80 relacionamento sexual do português com nativas dever-se-ia à mestiçagem deste e à influência cultural árabe, além da escassez de gente, e teria um propósito evangelizador.

9 Freyre usou pela primeira vez a expressão luso-tropicalismo, em Novembro de 1951, numa conferência em Goa, durante a viagem que Sarmento Rodrigues o convidou a fazer pelo Ultramar. 0 conceito foi desenvolvido em Aventura e rotina e Um brasileiro em terras portuguesas, publicados no Brasil em 1953. 
todas as instâncias com relevo político internacionalmente e ainda outras capazes de ajudar a operar uma mudança da opinião pública mundial.

Apesar da profusão de cópias de filmes da autoria de Pascal-Angot, de co-produção luso-belga, com narrações em várias línguas, depositadas na Cinemateca Portuguesa (CP), nunca tinha sido pesquisada - ou encontrada - a informação relativa aos mesmos. 0 mesmo se verificava quanto aos filmes de Jean Leduc. Foi no âmbito de uma pesquisa sobre o cinema de propaganda feito em Angola antes da independência que identifiquei o primeiro depósito de informação no Arquivo Nacional da Torre do Tombo (ANTT). Posteriormente, encontrei informação, que permanecia classificada como confidencial, no Arquivo Histórico Diplomático português (AHD).

\section{0 "Milagre" COLONial PORTUGUÊS MOSTRAdO AO MUNDO}

No final de 1963, a Internacional Audio-Vision (IAV) faz à Presidência do ConseIho uma proposta para fazer a propaganda internacional de Portugal através de documentários. 0 assunto foi mantido confidencial para assegurar o êxito da missão propagandista encetada pela produtora belga de que era representante Pascal-Angot.

A IAV anuncia que dedicará 1964 a Portugal e aos seus "territórios ultramarinos" de modo a facultar "um grande filme de prestígio nacional"; documentários de "prestígio e técnicos" quer para a propaganda directa, através dos serviços de informaç̧ão, quer para as relações públicas e documentação geral dos Ministérios públicos e documentários económicos. Complementarmente, propõe-se promover "uma acção de propaganda a longo prazo no exterior [...] e sublinha que "[...] difusão, por ser efectuada por uma organização não portuguesa, beneficiaria de possibilidades maiores, de mais amplo crédito, cujos resultados seriam incomparavelmente mais positivos para Portugal".

Após lamentar que, à data, Portugal seja dos poucos países a não dispor do mínimo de filmes ao gosto do público e que satisfaça as necessidades de propaganda exterior, explica que nisso radica o "mau conhecimento" e falta de compreensão sobre a realidade portuguesa no exterior. Atesta que, se organismos como o SNI e os Centros de Informação e Turismo cumprem a função propagandista no que ao público interno concerne, "a sua eficácia no exterior parece duvidosa para não dizer nula". Como exemplo negativo, comenta-se o que sucedeu com o filme Viagem presidencial a Angola - 1963, realizado por Perdigão Queiroga: "[...] as cadeias de televisão ignoraram sistematicamente os milhares de metros de película que a informação oficial Ihes enviou regularmente; as agências de informação não transmitiram aos jornais qualquer comentário sobre essa viagem".

Os argumentos vingaram mas a negociação dos termos da relação entre o Estado português e a produtora durou um ano. Nesse tempo apurou-se, junto dos vários ministérios, que filmes teria o Estado português interesse em produzir, custos e modo de financiamento além de questões técnicas. 0 processo, intermediado por César Moreira Baptista, resultou numa grande comparticipação do Ministério do Ultramar (MU) nesta acção de propaganda documental. 0 MU assegurou mais de metade do valor da proposta final aprovada - com o custo de 615 mil dólares - para a produção de filmes para todos os Ministérios. ${ }^{10}$

10 Posteriormente, em 1968, estreou uma série de curtas-metragens essencialmente sobre a economia da metrópole embora também abordando novos temas sobre a economia de Angola e ou- 
0 Plano Ultramar, cuja carta-contrato foi assinada entre o SNI e a IAV em 28 de Dezembro de 1964, previu a produção de nove filmes - em $35 \mathrm{~mm}$, a cores e com metragem previamente definida -, cinco dos quais sobre Angola e quatro sobre Moçambique. Custaram 9 mil contos, tendo 5500, pagos "pelos Governos-Gerais das duas províncias e pela Associação Portuguesa das Empresas do Ultramar", sido imediatamente depositados pelo MU no FCN. ${ }^{11}$ No total, desse primeiro plano, fizeram-se sete filmes, quatro sobre Angola e três sobre Moçambique dado que o MU aprovou a supressão de dois filmes curtos para aumentar a metragem de outros documentários - e com isso, potenciá-los - que abordaram conjuntamente as duas maiores "províncias ultramarinas". ${ }^{12}$ Em vez de dois filmes distintos, com 17 minutos cada, sobre a acção médico-social em Angola e Moçambique, reuniu-se 0 material num único documentário de 32 minutos.

A título de exemplo ilustrativo, Angola-Moçambique (acção médico-social), abre com um organigrama da organização da saúde procurando mostrar a modernidade das infraestruturas e a multirracialidade com imagens de negros e brancos investigando e fazendo análises laboratoriais nos institutos de investigação. Filma-se a vacinação em tabancas antes de prosseguir-se reportando o combate à malária (em Moçambique) - dando enfoque ao apoio da Organização Mundial de Saúde à lepra, à tuberculose. Moçambique turístico, Moçambique - o ensino, Moçambique - economia, Angola - o café, Angola - o ensino, Angola - economia foram os restantes filmes produzidos sendo que este último, que deveria ter 30 minutos, originalmente "cresceu" 515 metros por via da supressão do documentário artístico Angola [a diferença entre a metragem prevista para este - 821 metros - foi compensada em Moçambique - economia].

Como a titulação dos filmes sugere - procurando exibir uma suposta objectividade - estes são organizados como reportagens. Revelam qualidade na execução técnica e uma linguagem moderna inexistente na propaganda colonial estritamente política filmada por portugueses. Mostrar o progresso, o desenvolvimento e a modernidade, além da multirracialidade existente, são os eixos à volta dos quais se organiza a realização dos documentários que, através dos seus supostos repórteres, fazem eco do luso-tropicalismo apregoado.

Como contrapartida pela encomenda das séries designadas como Série Metrópole e Série Ultramar - e em função do valor total da mesma - Pascal-Angot realizou, gratuitamente, Portugal de hoje, o qual terá estreado em 25 de Maio de 1967. Na proposta original, propunha-se mostrar: "o país com todos os denominadores comuns, da metrópole ao Ultramar, passando por Macau e Timor, incluindo as ilhas

tras colónias. Tal deverá corresponder à diferença entre os 320 mil dólares gastos com nove filmes do Plano ou Série Ultramar e os 615 mil dólares do conjunto do pacote de que faz parte um Plano Metrópole - há, no ANTT, contratos de filmes sobre obras públicas, comunicações, etc. - proposto pela IAV. Ver ANTT, SNI/IGAC Caixa 671, processo 4.

11 A correspondência trocada atesta que Moreira Baptista foi informado dos motivos legais pelos quais o MU não podia celebrar o contrato com a International Audio-Vision através dos dois organismos que eventualmente o poderiam fazer: AGU ou Delegação Comercial do Ultramar.

12 Posteriormente Pascal-Angot filmou outros documentários relativos a colónias portuguesas mas ainda não localizei a informação relativa à produção dos mesmos e a totalidade dos títulos realizados. 
e África. Do grande quadro deve ressaltar, em grande plano, a unidade portuguesa na sua diversidade de tradições e raças".

Que recomendações trazia Pascal-Angot para o governo português the entregar um pacote de realização de filmes de orçamento tão elevado? ${ }^{13}$ Note-se que, à data, filmes de ficção do Novo Cinema português que então surgiam - como Os verdes anos (1963) ou Belarmino (1964) - custaram entre 800 e 900 contos, o preço cobrado por um destes documentários de 17 minutos entregue em três cópias.

Num parecer não datado escreve-se que é de acreditar na idoneidade moral e técnica do produtor e realizador proponentes - de Pascal-Angot conhecem-se os documentários que o reputam "um técnico de cinema de muito bom nível". Ao reconhecimento sobre a importância do documentário como meio de informação acresce uma avaliação da qualidade dos filmes portugueses desse género disponíveis:

A nossa cinemateca - e supomos que as de outros departamentos do Estado e empresas não são só pobres, como de baixo nível técnico [a lápis está escrito "isto não é verdade" e algo mais ilegível]. Não nos tem sido possível encontrar entre nós realizadores que assegurem o ritmo, a linguagem cinematográfica, e a objectividade inteligente nos documentários que lhes têm sido encomendados, nomeadamente quando visam fins de esclarecimento político. Em seu favor não deixará, no entanto, de se referir que também não lhes têm dado muitas oportunidades [...].

Considera-se, porém, que, "mesmo que fossem satisfatórias as provas dadas [pelos realizadores portugueses], ficaria sempre a restrição das dificuldades de assegurarem uma ampla difusão, o que só se obtém com ligações estreitas com as grandes empresas internacionais de distribuição". Conclui-se considerando que a proposta da IAV "parece oferecer bases suficientes à realização de uma boa campanha de esclarecimento da opinião pública internacional" quer tecnicamente quer através da relação com a 20th Century Fox e Fox Movietone.

Para a viabilização do plano parece ter sido determinante a prestação de serviços ao Institut Belge d'Information et Documentation, comprovada por carta de 13 de Novembro e assinada pelo director geral J.J.L. Van Overloop. Atesta que Pascal-Angot filmou, entre 1960 e 1962, por conta do governo tutelar belga no Ruanda-Urundi, vários documentários ${ }^{14}$ e que 0 cineasta fez uma longa-metragem documental sobre o Ruanda-Urundi que apresentava um balanço largamente positivo da acção belga nesta região de África. Finalmente, afirmava que Pascal-Angot soubera impôr-se perante o público internacional obtendo, em 1962, no Festival Internacional do Filme Documental, de Roma, uma Taça de Ouro.

13 Na proposta apresentada, o currículo descrevia-o como vencedor da Taça de Ouro 1962 do Festival Internacional do Filme Documentário de Roma; realizador de mais de 40 documentários de prestígio; acreditado nos principais organismos internacionais: ONU, OCDE, OMS, FA0; realizador de "Demain L'Angola" apresentado, a 7 de Junho de 1963, na Televisão Francesa no programa Cinque colones à la une (http://www.ina.fr/video/CAF93012462/demain-l-angola-video.html) e nas belga, suíça e canadense em Neuf millions.

14 L'agriculture, Le café, Le coton, La pêche, L'action médico-sociale, L'enséignment secondaire, L'enséignment professionnel, Le lac Tanganika, Le tourisme, Les élections, Le verminose, Le kwaskiorkor. 
No entanto, a condição fundamental que viabilizou o Plano Ultramar foi o plano de distribuição dos filmes. A IAV comprometeu-se a apresentar os filmes aos organismos internacionais especializados. À Organização para a Cooperação e Desenvolvimento Económico (OCDE) e à European Free Trade Association (EFTA) apresentar-se-iam os documentários sobre a economia e/ ou filme de prestígio. À Food Agriculture Organisation (FAO) mostrar-se-ia Angola - o café, Angola - economia e Moçambique - Economia; à United Nations Educational, Scientific and Cultural Organization (UNESCO), Angola - o ensino e Moçambique - o ensino, e ao United Nations Children's Fund (UNICEF) e à Organização Mundial de Saúde (OMS), Angola - Moçambique (acção médico-social). ${ }^{15}$ A IAV firmou ainda um acordo com a 20th Century Fox para a distribuição internacional de alguns filmes ficando garantido 0 carácter apolítico dos comentários dos filmes.

Documentação existente no AHD comprova que a difusão foi bem sucedida no que respeita à exibição dos filmes aos organismos internacionais visados. No que respeita à NATO, por exemplo, relata-se:

[...] A pedido da delegação portuguesa à NATO, em Paris, e do Gabinete dos Assuntos Políticos do Ministério do Ultramar, organizámos uma apresentação oficiosa dos filmes Ultramar para o Director da Informação da NATO, encarregue de apreciar o carácter apolítico [sublinhado do autor] dos nossos documentários para dar "luz verde" a uma projecção oficial destes filmes a acontecer em Março, durante a Assembleia da NATO em Lisboa. A conclusão desta Alta Autoridade foi inteiramente favorável e a apresentação dos filmes, perante a Assembleia da NATO, decorreu efectivamente em Lisboa, a 22 de Março de 1966.

A orientação dos temas dos filmes do Plano Ultramar ficou a cargo do MU e as cópias-zero foram apresentadas para apreciação por grupos de trabalho com representantes de vários ministérios. Nos dois relatórios que encontrei e pude consultar, relativos a Angola - o ensino e Angola - Moçambique (acção médico-social), sobre o primeiro diz-se que é "Tecnicamente bem realizado e inteligentemente concebido". Nesse documento, datado de 3 de Julho de 1965, o inspector Júlio Monteiro, representante da Direcção Geral de Ensino, considera que o filme apresenta "uma série elucidativa de apontamentos válidos, cheios de espontaneidade, revela uma inestimável alegria de viver das gentes, um optimismo saudável e contagioso que não tem preço - mas não é o que ele gostaria de ver realizado sobre a educação em Angola". Aponta duas falhas, afirmando que podem ser supridas: a escola do magistério público de Bela Vista, que prepara "professoras" [aspas do relatório] nativas, equivalente à escola do Cuima, merecia ter sido focada ao lado desta "tanto mais que ela demonstra também a preocupação que está merecendo a preparação da mulher nativa" e "a representação visual, através de duas ou três pequenas sequências do lema que está norteando a política do ensino primário em Angola: levar a escola à sanzala". Diz, porém, que como espectador o filme lhe agrada "pelo equilíbrio, pela beleza e pelo colorido das imagens, que são magníficas".

15 Além dos filmes sobre Moçambique, naturalmente. 
No segundo relatório, assinado a 15, o representante da tutela, Martins Barbosa, considerou que se deu demasiado relevo à acção da OMS mas os restantes membros do grupo de trabalho consideraram isso positivo dado que a exibição do filme visava o estrangeiro.

Documentação existente comprova, com detalhe, que a IAV cumpriu com o contratado quanto à distribuição internacional dos filmes enquanto que, em Portugal, os mesmos foram programados em diversas sessões realizadas por várias entidades além de terem sido mostrados em Angola e Moçambique. Sequências dos filmes foram utilizadas pelas Actualités Françaises, o filme sobre Angola e Moçambique foi mostrado no festival de cinema de S. Francisco seguindo depois para Veneza, para o Festival del Popoli, além de 0 café ter passado no Festival do Filme Cultural de Tóquio e obtido uma Medalha de Ouro no festival em Veneza. Certo é que o governo português ficou satisfeito com o cumprimento do Plano Ultramar, ou não teria encomendado a Pascal-Angot vários outros documentários sobre a economia da metrópole e das colónias que foram sendo estreados no final da década de 60 . Também não teria reincidido, como o fez, com a série de documentários Africarama $n^{\circ} 1$ e 2 - Angola, de 1971. No que se refere a este segundo a simulação de objectividade de um trabalho jornalístico é álibi para a propaganda à política colonial portuguesa e responde a reportagens internacionais críticas da mesma. Em jeito de preâmbuIo, afirma-se que a política colonial portuguesa tem sido um assunto controverso mas que, neste filme, repórteres brasileiros, alemães e franceses apresentam novos dados sobre o tema que as pessoas tendem a esquecer "no calor da discussão".

0 documentário começa dando enfoque ao desenvolvimento económico, referindo que é quatro vezes superior ao britânico e o maior em África. A questão racial é comentada afirmando-se que há uma política não racista embora as diferenças de nível de vida ainda sejam lamentáveis. Acrescenta-se que, na última década, a diferença diminuiu a imagem que o ilustra é a de brancos e pretos a entrar, sem distinção, para autocarros. Sustenta-se que, se o cenário multirracial não é tão idílico como a propaganda mostra - e deste modo procura demarcar-se da propaganda oficial do regime como se não fosse também financiado pela ditadura portuguesa -, o facto é que ele existe, apoiado pela classe baixa e média, maioritárias. 0 Brasil - a maior comunidade multirracial do mundo, diz-se - surge, depois, como o grande argumento a favor de Portugal. Documentação existente no AHD comprova que a abordagem das relações entre Portugal e o Brasil foi visada como central neste projecto embora acautelando susceptibilidades:

No filme a realizar não se deveria apenas focar o paralelismo existente entre o Brasil e a África Portuguesa sendo necessário pôr igualmente em evidência os numerosos pontos de contacto do Brasil com a Metrópole e isto no intuito de não susceptibilizar o público brasileiro.

Africarama $n^{0} 2$ afirma que a população se manteve, em geral, indiferente à propaganda dos movimentos subversivos vindos de fora e que o governo prometeu uma melhor distribuição das responsabilidades administrativas quando as universidades produzirem pessoas qualificadas suficientes. Sobre o crescimento industrial, assume-se que políticas de trabalho e sindicalismo são ainda, talvez, paternalistas mas que, em contrapartida, são os mais desenvolvidos de África. 
Sem 0 fado mas com Fátima e futebol. Assim são organizados os eixos relativos aos tempos livres e à espiritualidade da população em Angola. Afirma-se que a guerrilha se mantém fora das fronteiras e que a comunidade dedica-se aos prazeres iguais aos de outros países - como o futebol. Sublinha-se um suposto "fenómeno português": o do sucesso de cinco séculos de presença portuguesa, uma retórica decalcada do luso-tropicalismo freyriano.

A questão económica é retomada depois, com a agricultura como actividade dominante mas também a nova exploração de petróleo em Cabinda. As vias de transporte e as barragens são comentadas ainda antes da evocação das universidades criadas desde há uma década. "Portugal está convencido que a educação é o único modo de obter a integração racial", afirma-se. Explica-se ainda que para votar é preciso ter a quarta-classe logo antes de reconhecer-se que só há um partido e sugerir que "a liberalização política é sempre possível".

Também o francês Jean Leduc (1922-96), realizador do filme de ficção Capitão Singrid (1967) rodado em Angola e estreado em Portugal em 1970, no início dessa década filma vários documentários de propaganda com enfoque turístico que dão eco ao discurso colonial do regime. Data de 1967, porém, o primeiro documentário "angolano" - cuja realização divide com Felipe de Solms - que, provavelmente, foi rodado enquanto realizava o filme de ficção. Aspectos da nossa Angola usa música do Duo Ouro Negro e adopta o registo em modo reportagem. Inclui filmagens aéreas de Luanda antes de descer ao Mussulo e mostrar que nas suas praias de sonho há raparigas em biquini. Faz o trajecto da costa para fixar os testemunhos da presença portuguesa antes de rumar a norte onde, "apesar da eclosão do terrorismo", o café continua a alimentar a economia. Após a "passagem" por Benguela e pelo planalto, exibe um apontamento sobre os penteados das mulheres da região. 0 deserto de Moçâmedes e o Namibe são mostrados ainda antes da exibição da arquitectura moderna, do elogio às actividades económicas e a reportagem do Lobito, com direito à alusão ao caminho de ferro. Passado e futuro, tradição e modernidade do colonialismo português, são as notas dominantes. Há, porém, uma marca específica de Leduc: é a da exploração erotizada da figura feminina na promoção de Angola.

Já no início da década de 70, L'Angola a tire de l'aie (Angola a olho de pássaro), filma o território a partir do ar, mostrando os locais mais emblemáticos, turísticos ou em termos de progresso económico, reproduzindo a perspectiva histórica portuguesa, que vai enunciando como comentário às imagens. A curta-metragem Angola Flashé uma co-produção luso-francesa que mostra Angola tendo uma modelo internacional como cicerone. A auxiliá-la está Melita, mestiça local muito atraente e moderna. São ambas filmadas nos cenários onde, supostamente, Denise Destree é protagonista de uma campanha de moda fotografada por Walter Anger. África selvagem, dos animais, a Angola tribal mas também a Luanda moderna, da multirracialidade, servem de cenário exótico para a produção. Denise vai registando mentalmente as suas impressões - partilhadas em voz off - até a um momento de crise interior, quando está na praia, e se sente enclausurada devido à circunstância de ter de trabalhar quando devia antes estar de férias. 0 seu desejo de liberdade, simbolizado por uma corrida na praia, em fato de banho - corrida em que é seguida por Melita - é um dos momentos chave do filme devido à erotização das figuras femininas e aproximação à série dos James Bond. Depois de ir a uma tourada e de visitar as 
quedas do Duque de Bragança, Denise parte e promete voltar mas não como "cover girl". A música dos Ouro Negro e de Dino Castro serve o exotismo da abordagem. Rythme de Luanda, feito pela mesma equipa e com música dos Ouro Negro e dos Negoleiros do Ritmo, é mais um filme sobre a multirracialidade e a modernidade tropical de Luanda. Mostra imagens de pescadores, brancos e negros, trabalhando lado a lado; máscaras africanas mas também de azulejaria portuguesa; há uma tourada e uma corrida de automóveis; pesca desportiva e um caçador transportado de avioneta. É a capital luso-tropical que se oferece ao mundo moderno ocidental como destino turístico exótico e moderno.

0 grande filme de propaganda assinado por Leduc, que retoma o registo da reportagem é, no entanto, a média-metragem Le Portugal d'Outre Mer dans le monde d'aujord'hui. É o próprio Leduc quem surge, a fazer entrevistas, em Macau, Timor, Cabo Verde, S. Tomé e Guiné-Bissau antes da passagem por Angola e o remate do documentário em Moçambique.

A retórica luso-tropical ecoa em todo o filme e, a legitimá-la, surge o presidente do conselho de então, Marcelo Caetano, em entrevista. Afirma: "Não temos espírito de superioridade racial nem o sentido de dominação nem percepção de exploração dos povos de África. Todas essas marcas do colonialismo faltam na presença portuguesa em África".

0 filme dá, de novo, enfoque à modernidade e multirracialismo de Luanda. Refere-se o progresso e mostra-se a arquitectura antiga da cidade a par da "ultramoderna". Um jovem casal de negros é filmado antes de ver-se uma mestiça a comprar roupa desfilada por uma modelo europeia.

À tradição portuguesa, simbolizada numa tourada, sucedem-se imagens de progresso, numa barragem e numa cidade colonial. Sucedem-se imagens de actividades económicas e Leduc entrevista um grande empresário do café, dono de sete fazendas nas quais trabalham duas mil pessoas durante a fase das colheitas. Pergunta o realizador se há problemas de segurança ao que 0 empresário responde que não mas que, por lei, são obrigados a manter segurança privada. Também as mulheres participam na defesa e o documentário mostra imagens ilustrativas. 0 empresário diz que o futuro é um problema económico e não político. Afirma que, se houver um desenvolvimento económico rápido, o problema político não se coloca.

0 filme mostra a fronteira com o Congo e sustenta-se que reina a tolerância [um comboio passa sob a vigilância de um soldado]. Nova entrevista, desta vez ao director do caminho de ferro, o qual prevê um futuro grandioso para Angola. "Tem muitas possibilidades. No futuro podemos construir uma sociedade muito harmoniosa, como no Brasil, com todos os problemas económicos resolvidos. [...] Vejo Angola na África como uma projecção da Europa".

\section{EPÍLOGO}

Quando os filmes começaram a tornar-se um negócio rentável, em Moçambique ou Angola, e fizeram despontar a produção de cinema local, continuava a não existir um cinema moçambicano ou angolano. 0 movimento cineclubista, que emergiu na década de 50, começou a educar o olhar dos cinéfilos ou simplesmente dos que viram no cinema uma arma. 0 cinema feito nas ex-colónias portuguesas quando nasce é, naturalmente, o contraponto à voz da propaganda colonialista portuguesa. 
Não se pode, pois, escamotear o papel que filmes como os de Pascal-Angot, financiados secretamente ao mais alto nível, tiveram na difusão de uma retórica luso-tropical que ainda hoje ecoa no discurso da lusofonia.

A desmontagem do dispositivo retórico colonial filmado do Estado Novo é ainda incipiente. Este é um contributo para que se comece a preencher este quase vazio. Questiono a consciência crítica sobre o que somos hoje - um "conhece-te a ti mesmo" no sentido gramsciano - a partir desta análise da projecção do homem pelo cinema, a partir da infinidade de traços deixada também nestes filmes da propaganda, considerando-os como "filme-palimpsesto" (Lindeperg). Trata-se de considerar o filme mais o inventário das várias camadas de escrita sobre o filme e as suas imagens como objecto de análise. Lindeperg diz que o seu método convida a "passar por detrás do ecrã" para ir do visível ao inteligível ao considerar a imagem projectada não como um reflexo mas como um sintoma, uma alteração da percepção comum sobre o que esta mostra. De que é a imagem de cinema sintoma, pergunta Lindeperg? Do resultado de uma operação - da relação entre um lugar (um discurso profissional ou político), um conjunto de procedimentos (a prática cinematográfica) e a construção de um discurso. ${ }^{16}$ Retenho, por outra via, a proposta, pelo historiador de arte e antropólogo visual Georges Didi-Huberman, de que a imagem deve ser olhada como um sintoma e não como síntese. Complemento assim a análise do filme como palimpsesto, com a análise de imagem e a "aproximação" de imagens e dos textos produzidos sobre elas - enquadrada pelo "conhecimento-montagem" proposto por Didi-Huberman -, com a expectativa que tal gere não um vislumbre da verdade mas imagens-clarão fugazes sobre o "homem [colonial] imaginado" pelo cinema de propaganda português.

\section{REFERÊNCIAS BIBLIOGRÁFICAS}

Castelo, C. (1999). O modo português de estar no mundo. Porto: Afrontamento.

Didi-Huberman, G. (2012). Imagens apesar de tudo. Lisboa: Imago.

Foucalt, M. (1997). A ordem do discurso. Lisboa: Relógio d’Água.

Freyre, G. (s.d.). Aventura e rotina. Lisboa: Livros do Brasil

Freyre, G. (s.d.). $O$ mundo que o português criou - Aspectos das relações sociais e de cultura do Brasil com Portugal e as colónias portuguesas. Lisboa: Livros do Brasil.

Frodon, J.-M. (1998). La projection nationale. Cinéma et nation. Paris: Odile Jacob.

Lindeperg, S. (2004). Itinéraires: Le cinéma et la photographie à l'épreuve de l'histoire. Cinémas: Revue d'Études Cinématographiques, 14, n²-3, 191-210. Acedido em http:// id.erudit.org/iderudit/026009ar

Lindeperg, S. (2007). "Nuit et brouillard" un film dans I'histoire. Paris: Odile Jacob.

Piçarra, M. d. C. (2015). Azuis ultramarinos. Propaganda e censura no cinema do Estado Novo. Lisboa: Edições 70.

16 Entendo discurso na acepção que lhe deu Foucault: um conjunto de enunciados que podem pertencer a campos diferentes mas que obedecem a regras de funcionamento comuns. Estas regras não são só formais ou linguísticas mas reproduzem certas partilhas historicamente determinadas: a "ordem do discurso" própria de um período particular possui uma função normativa e regulada e acciona mecanismos de organização do real através da produção de saberes, estratégias e práticas (Foucault, 1997). 
Piçarra, M. d. C. (2013) (coord.). Angola: O nascimento de uma nação. Cinema império. Lisboa: Guerra \& Paz.

Piçarra, M. d. C. (2013). “0 império contra-ataca: produção secreta de filmes coloniais para projecção mundial". In Os cinemas dos países lusófonos. V Simpósio internacional/VII Mostra. Coord. Jorge Cruz e Leandro Mendonça. UERJ/UFF Rio de Janeiro: Edições LCV.

Pimentel, J. (2002). "La collection coloniale de la Cinemateca Portuguesa" in Journal of Film Preservation. 64 (Abril de 2002).

Said, E. (1996). Cultura e imperialismo. Barcelona: Anagrama.

FONTES ARQUIVÍSTICAS:

ANTT, SNI/IGAC Caixa 671, processo 4.

PT/AHD/MU/GM/GNP/RNP/0123/01244

PT/AHD/MU/GM/GNP/RNP/0438/00395

PT/AHD/MU/GM/GNP/RNP/0661/02991 